\title{
Spectrophotometric Simultaneous Determination of Salbutamol Sulfate and Ketotifen Fumarate in Combined Tablet Dosage Form by First-Order Derivative Spectroscopy Method
}

\author{
Parth R. Joshi, Shraddha J. Parmar, and Bhavna A. Patel \\ Postgraduate Department of Pharmaceutical Sciences, Sardar Patel University, Vallabh Vidyanagar, Anand, Gujarat 388120, India \\ Correspondence should be addressed to Parth R. Joshi; parth142j@gmail.com
}

Received 31 May 2013; Revised 21 June 2013; Accepted 9 July 2013

Academic Editor: Rolf W. Berg

Copyright (c) 2013 Parth R. Joshi et al. This is an open access article distributed under the Creative Commons Attribution License, which permits unrestricted use, distribution, and reproduction in any medium, provided the original work is properly cited.

\begin{abstract}
Salbutamol sulfate and ketotifen fumarate are used in combination for the treatment of asthma. The present work deals with method development for simultaneous estimation of salbutamol sulfate and ketotifen fumarate in two-component tablet formulation by first-order derivative spectroscopy. For determination of sampling wavelength, $10 \mu \mathrm{g} / \mathrm{mL}$ of each of salbutamol and ketotifen was scanned in 200-400 $\mathrm{nm}$ ranges and sampling wavelengths were found to be $257 \mathrm{~nm}$ for salbutamol and $278 \mathrm{~nm}$ for ketotifen in firstorder derivative spectroscopy. In this method, linearity was observed in the ranges of $5-45 \mu \mathrm{g} / \mathrm{mL}$ for salbutamol and 5-35 $\mu \mathrm{g} / \mathrm{mL}$ for ketotifen. The \% recovery was within the range between 98 and 102\%, and \% relative standard deviation for precision and accuracy of the method was found to be less than $2 \%$. The method is validated as per international conference on harmonization guidelines. The method can be successfully applied for the simultaneous analysis of both drugs in pharmaceutical dosage forms.
\end{abstract}

\section{Introduction}

Salbutamol sulfate, chemically known as (rs)-1-(4-hydroxy3-hydroxymethylphenyl)-2-(tert-butylamino) ethanol sulfate (Figure 1), is beta-adrenoceptor agonist used as an antiasthmatic drug [1]. It is official in Indian pharmacopoeia and British pharmacopoeia. It is estimated by acid-base titration method as per Indian pharmacopoeia and British pharmacopoeia $[1,2]$. The literature review reveals that HPLC [3-5] and UV spectrophotometric methods [6-8] have been reported for estimation of salbutamol sulfate in pharmaceutical dosage forms.

Ketotifen fumarate, chemically known as 4-(1-methyl-4piperidylidene)-4h-benzo [4, 5] cyclohepta [1, 2-b] thiophen$10(9 \mathrm{~h})$-one hydrogen fumarate (Figure 2), is cycloheptathiophene blocker of histamine $\mathrm{h}-1$ receptors used as an antiallergic and an antiasthmatic drug [9]. It is not official in Indian pharmacopoeia, British pharmacopoeia, United States pharmacopoeia, and European pharmacopoeia. The literature review reveals that HPLC $[10,11]$ and UV spectrophotometric methods $[12,13]$ have been reported for estimation of ketotifen fumarate in pharmaceutical dosage forms.
The salbutamol sulfate and ketotifen fumarate mixture is not yet official in any pharmacopoeia. As per literature, no analytical method could be traced for the analysis of salbutamol sulfate and ketotifen fumarate combination in pharmaceutical dosage forms. Therefore, simple, rapid, and reliable method for simultaneous estimation of these drugs in mixture seemed to be necessary.

Spectrophotometric methods of analysis are more economic and simpler, compared to methods such as chromatography and electrophoresis. Under computer-controlled instrumentation, derivative spectrophotometry is playing a very important role in the multicomponent analysis of mixtures by UV molecular absorption spectrophotometry. Binary mixtures can be easily resolved by means of a spectrophotometric method, which is based on the simultaneous use of "zero crossing" method. The aim of this work was to investigate the utility of derivative spectrophotometry and to develop reliable spectrophotometric procedures for the simultaneous determination of salbutamol sulfate and ketotifen fumarate either in laboratory samples or in commercial dosage forms without any prior separation of individual drugs. The present developed method is simple, rapid, 


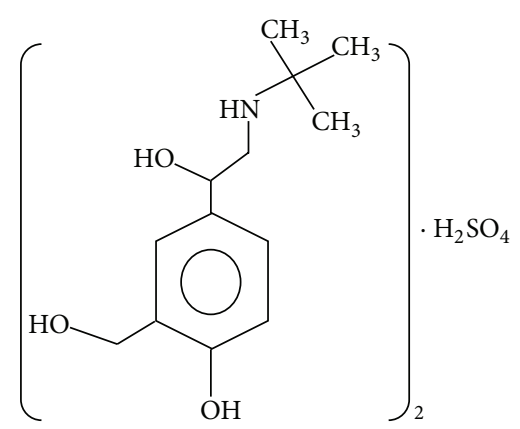

FIGURE 1: Chemical structure of salbutamol sulfate.

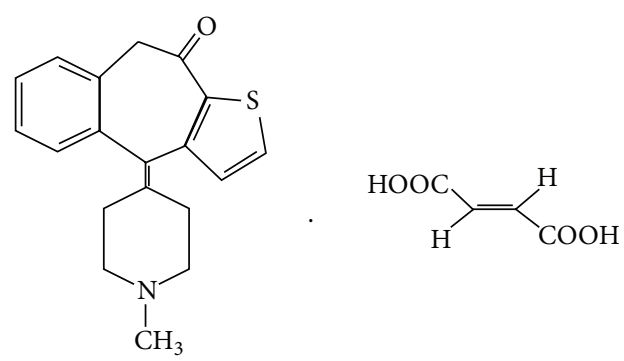

FIGURE 2: Chemical structure of ketotifen fumarate.

precise, and accurate for simultaneous determination of both drugs in binary mixture as per international conference on harmonization guidelines $[14,15]$.

\section{Materials and Methods}

2.1. Apparatus and Instrument. A double beam UV-visible spectrophotometer (Shimadzu, model pharm spec 1800) having two matched quartz cells with $1 \mathrm{~cm}$ light path and electronic analytical balance (Shimadzu AUX-220), and ultrasonication (Branson) were used. Volumetric flasks and pipettes of borosilicate glasses were used in the study.

2.2. Chemicals and Reagents. Pure drug samples of salbutamol sulfate and ketotifen fumarate were provided as a gift sample by East West Pharma, Uttarakhand, India. Methanol and all other chemicals were provided by Sardar Patel University, Vallabh Vidhyanagar, Gujarat, India.

2.3. Marketed Formulation. The marketed formulation studied was mastifen-s tablet manufactured by East West Pharma. Each tablet contains $1 \mathrm{mg}$ ketotifen and $2 \mathrm{mg}$ salbutamol.

2.4. Selection of Common Solvent. Methanol of analytical reagent grade was selected as a common solvent for developing spectral characteristics of both drugs. The selection was made after assessing the solubility of both drugs in different solvents.

2.5. Preparation of Standard Solutions. Accurately weighed quantity of salbutamol sulfate (10 mg) and ketotifen fumarate $(10 \mathrm{mg})$ was transferred to two separate $10 \mathrm{~mL}$ volumetric flasks, dissolved in little amount of methanol and diluted to the mark with methanol (stock solutions: $1000 \mu \mathrm{g} / \mathrm{mL}$

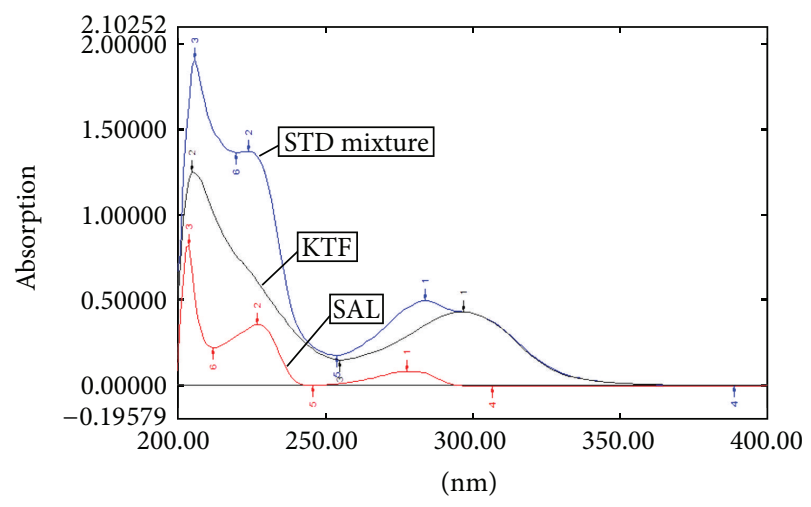

FIGURE 3: Absorption (zero order) UV spectra of salbutamol sulfate $(10 \mu \mathrm{g} / \mathrm{mL})$, ketotifen fumarate $(10 \mu \mathrm{g} / \mathrm{mL})$, and standard mixture $(10 \mu \mathrm{g} / \mathrm{mL}$ of ketotifen fumarate $+20 \mu \mathrm{g} / \mathrm{mL}$ of salbutamol sulfate) .

of salbutamol sulfate and ketotifen fumarate). $100 \mu \mathrm{g} / \mathrm{mL}$ of salbutamol sulfate and ketotifen fumarate solutions was prepared by diluting $5 \mathrm{~mL}$ of stock solution to $50 \mathrm{~mL}$ with methanol.

\subsection{Spectrophotometric Conditions}

(i) Mode: spectrum.

(ii) Scan speed: medium.

(iii) Bandwidth: $1 \mathrm{~nm}$.

(iv) Wavelength range: $400-200 \mathrm{~nm}$.

(v) Absorbance scale: $0.00 \mathrm{~A}-2.00 \mathrm{~A}$.

(vi) Initial baseline correction: methanol.

\section{First-Order Derivative Spectroscopy Method}

Working standard solutions of salbutamol sulfate $(100 \mu \mathrm{g} /$ $\mathrm{mL})$ and ketotifen fumarate $(100 \mu \mathrm{g} / \mathrm{mL})$ were diluted appropriately with methanol to obtain solution containing salbutamol sulfate $(10 \mu \mathrm{g} / \mathrm{mL})$ and ketotifen fumarate $(10 \mu \mathrm{g} / \mathrm{mL})$. Spectra of these diluted solutions were scanned in the spectrum mode between $200 \mathrm{~nm}$ and $400 \mathrm{~nm}$ using methanol as a blank. The zero-order spectra of salbutamol sulfate and ketotifen fumarate were transformed to corresponding first derivative spectra in the range of $200-400 \mathrm{~nm}$. The overlay spectra (zero and first order) of salbutamol sulfate and ketotifen fumarate are shown in Figures 3 and 4.

3.1. Selection of Wavelengths. A signal at $257 \mathrm{~nm}$ of first derivative spectrum was selected for quantification of salbutamol sulfate where no interference due to ketotifen fumarate was observed; similarly, a signal at $278 \mathrm{~nm}$ was selected for quantification of ketotifen fumarate, where salbutamol sulfate did not interfere with the estimation of ketotifen fumarate.

3.2. Calibration Curves for Salbutamol Sulfate and Ketotifen Fumarate. The standard solutions of salbutamol sulfate $(100 \mu \mathrm{g} / \mathrm{mL})$ and ketotifen fumarate $(100 \mu \mathrm{g} / \mathrm{mL})$ were used 


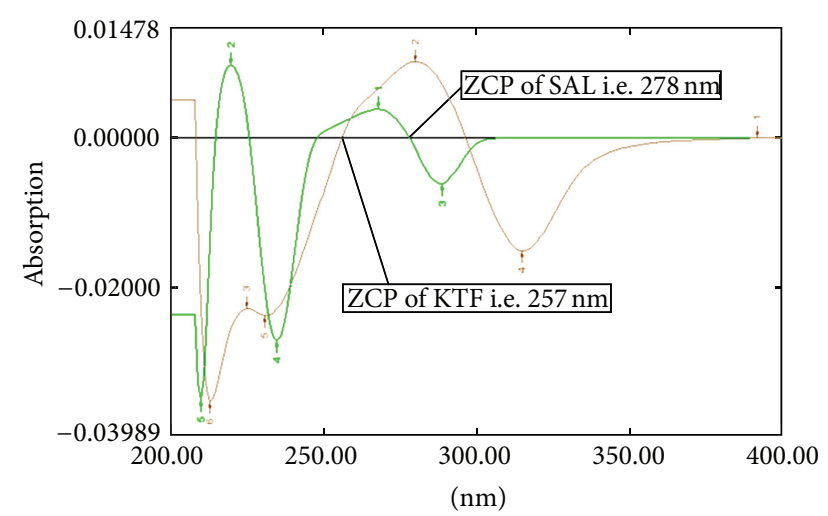

FIGURE 4: First-order derivative UV spectra of salbutamol sulfate $(10 \mu \mathrm{g} / \mathrm{mL})$ and ketotifen fumarate $(10 \mu \mathrm{g} / \mathrm{mL})$.

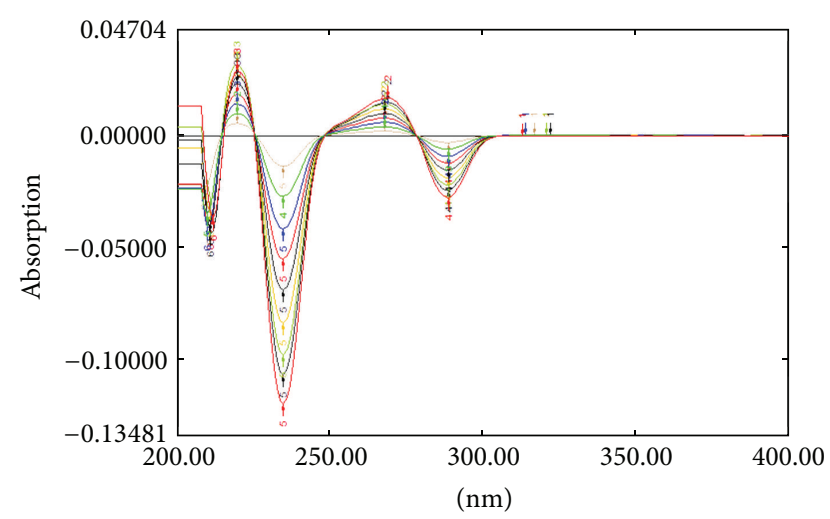

Figure 5: First-order derivative linearity spectra of salbutamol sulfate $(5-45 \mu \mathrm{g} / \mathrm{mL})$.

to prepare two different sets of working standard solutions of salbutamol sulfate $(5-45 \mu \mathrm{g} / \mathrm{mL})$ and ketotifen fumarate (5$35 \mu \mathrm{g} / \mathrm{mL})$. For this, aliquots of $0.5,1.0,1.5,2.0,2.5,3.0,3.5$, 4.0 , and $4.5 \mathrm{~mL}$ of working standard solutions of salbutamol sulfate and aliquots of $0.5,1.0,1.5,2.0,2.5,3.0$, and $3.5 \mathrm{~mL}$ of working standard solutions of ketotifen fumarate were transferred separately to a series of $10 \mathrm{~mL}$ volumetric flasks and diluted to mark with methanol, and the absorbance was measured at $257 \mathrm{~nm}$ for salbutamol sulfate and $278 \mathrm{~nm}$ for ketotifen fumarate, respectively. The values of first derivative absorbance were plotted against corresponding concentrations to construct the calibration curves. First derivative spectra of working standard dilutions and calibration curves are shown in Figures 5, 6, 7, and 8.

3.3. Analysis of Tablet Formulation. Marketed tablet formulations containing salbutamol sulfate $(2 \mathrm{mg})$ and ketotifen fumarate $(1 \mathrm{mg})$ were analyzed using this method. From the triturate of 20 tablets, an amount equivalent to $2 \mathrm{mg}$ of salbutamol sulfate and $1 \mathrm{mg}$ of ketotifen fumarate was weighed and dissolved in $10 \mathrm{~mL}$ of methanol in $100 \mathrm{~mL}$ volumetric flask by sonication for $10 \mathrm{~min}$. Then, final volume of the solution was made up to $100 \mathrm{~mL}$ with methanol to get a solution containing $20 \mu \mathrm{g} / \mathrm{mL}$ of salbutamol sulfate and $10 \mu \mathrm{g} / \mathrm{mL}$ of ketotifen fumarate. The solution was filtered through Whatman filter

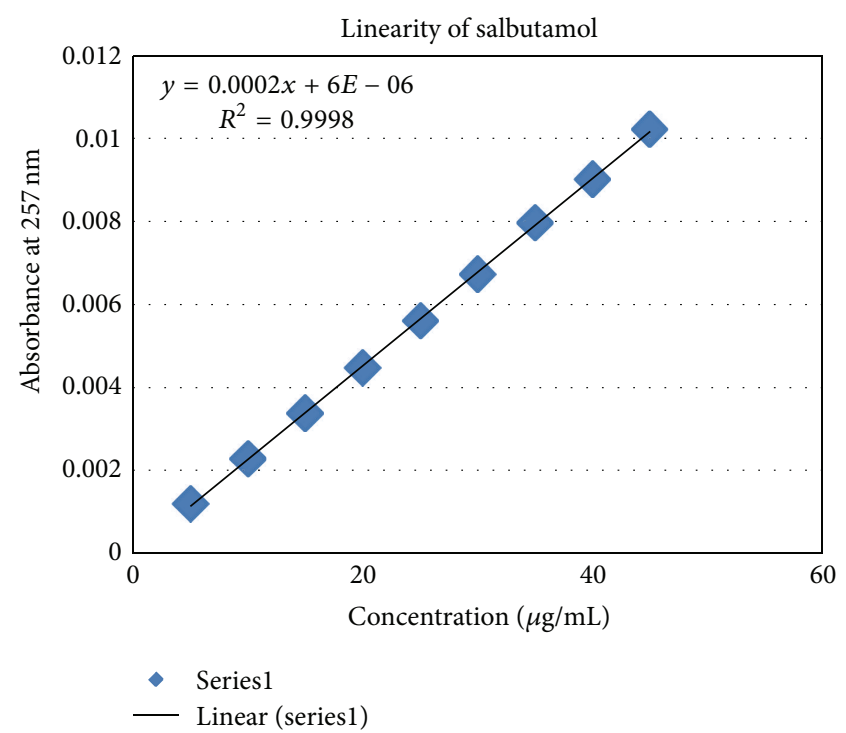

Figure 6: Calibration curve of salbutamol sulfate $(5-45 \mu \mathrm{g} / \mathrm{mL})$.

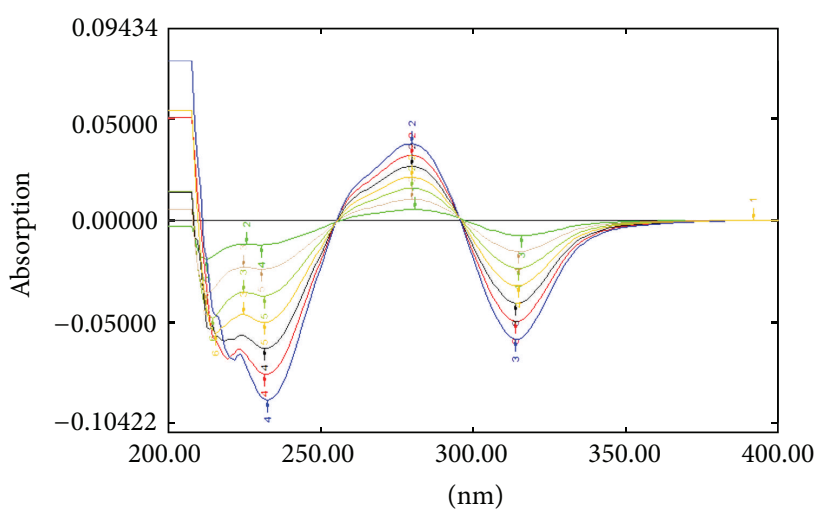

FIGURE 7: First order derivative linearity spectra of ketotifen fumarate $(5-35 \mu \mathrm{g} / \mathrm{mL})$.

paper no. 41, and the absorbance values were measured at $257 \mathrm{~nm}$ and $278 \mathrm{~nm}$ for salbutamol sulfate and ketotifen fumarate, respectively. The concentration of each analyte was determined with the equations generated from calibration curve of respective drugs. The first derivative spectrum of marketed formulation and standard mixture are shown in Figure 9. The analysis was repeated three times.

\section{Results and Discussion}

4.1. Selectivity. The UV spectra of standard mixture (salbutamol sulfate $(20 \mu \mathrm{g} / \mathrm{mL})+$ ketotifen fumarate $(10 \mu \mathrm{g} / \mathrm{mL}))$ and sample solutions (tablet) were recorded between 200 and $400 \mathrm{~nm}$ and their absorbance measured. The selectivity of the method was assessed by comparing spectra obtained from formulation solutions with that obtained from standard drug solution. The UV absorption spectra obtained from standard and sample solutions were found to be identical, confirming the selectivity of the method. The overlain UV absorption spectra of the drugs from marketed formulation (tablet) with the standard mixture are shown in Figure 9. 
TABLE 1: Recovery data for the proposed method.

\begin{tabular}{|c|c|c|c|c|c|c|}
\hline Drug & $\begin{array}{l}\text { Conc. of sample } \\
\text { taken }(\mu \mathrm{g} / \mathrm{mL})\end{array}$ & $\begin{array}{l}\text { Conc. of pure API } \\
\text { spiked }(\mu \mathrm{g} / \mathrm{mL})\end{array}$ & $\begin{array}{l}\text { Total conc. } \\
(\mu \mathrm{g} / \mathrm{mL})\end{array}$ & $\begin{array}{l}\text { Mean total conc. } \\
\text { found }(n=3) \\
(\mu \mathrm{g} / \mathrm{mL})\end{array}$ & $\begin{array}{l}\text { \%Recovery mean } \\
\qquad(n=3)\end{array}$ & $\% \mathrm{RSD}^{\mathrm{a}}$ \\
\hline \multirow{3}{*}{ SAL } & 20 & 16 & 36 & 36.26 & 100.73 & 0.48 \\
\hline & 20 & 20 & 40 & 39.86 & 99.65 & 0.73 \\
\hline & 20 & 24 & 44 & 44.02 & 100.04 & 0.11 \\
\hline \multirow{3}{*}{ KTF } & 10 & 8 & 18 & 18.06 & 100.33 & 1.29 \\
\hline & 10 & 10 & 20 & 20.24 & 101.21 & 0.69 \\
\hline & 10 & 12 & 22 & 21.90 & 99.58 & 1.26 \\
\hline
\end{tabular}

${ }^{a} \%$ relative standard deviation.

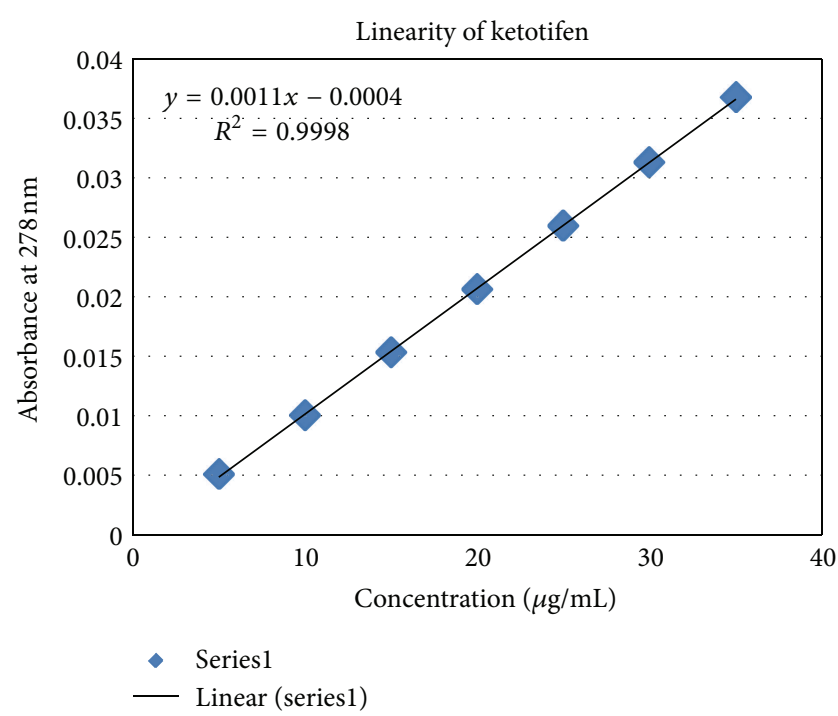

FIGURE 8: Calibration curve of ketotifen fumarate $(5-35 \mu \mathrm{g} / \mathrm{mL})$.

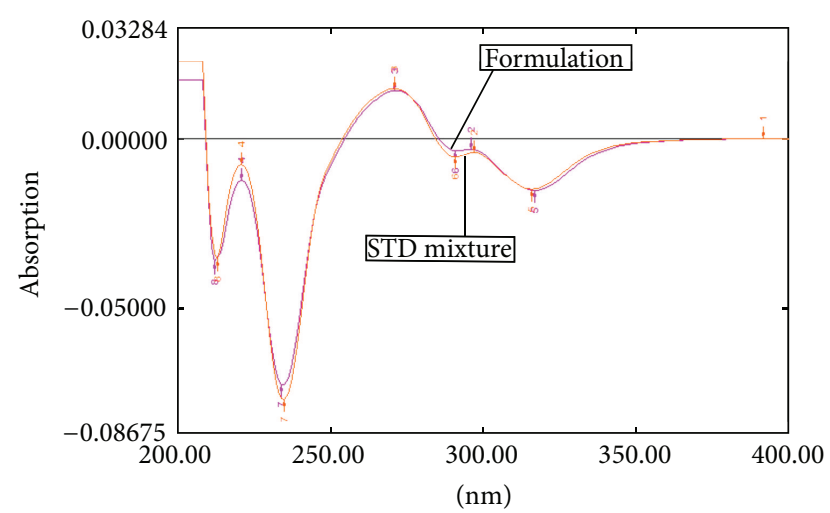

FIGURE 9: First-order overlay spectra of standard mixture $(10 \mu \mathrm{g} / \mathrm{mL}$ ketotifen fumarate $+20 \mu \mathrm{g} / \mathrm{mL}$ salbutamol sulfate) and marketed formulation.

4.2. Linearity. Linear correlation was obtained between absorbance versus concentrations of salbutamol sulfate and ketotifen fumarate in the concentration ranges of $5-45 \mu \mathrm{g} / \mathrm{mL}$ and $5-35 \mu \mathrm{g} / \mathrm{mL}$ for both drugs, respectively. Regression parameters are mentioned in Table 4 . The linearity spectra and calibration curves of salbutamol sulfate and ketotifen
TABLE 2: Repeatability data for proposed method.

\begin{tabular}{lccc}
\hline Sr. no. & $\begin{array}{c}\text { Concentration } \\
(\mu \mathrm{g} / \mathrm{mL})\end{array}$ & $\begin{array}{c}\text { Absorbance of } \\
\text { salbutamol sulfate } \\
\text { at } 257 \mathrm{~nm}\end{array}$ & $\begin{array}{c}\text { Absorbance of } \\
\text { ketotifen fumarate } \\
\text { at 278 nm }\end{array}$ \\
\hline 1 & $10 \mathrm{ppm}$ & 0.00227 & 0.01004 \\
2 & $10 \mathrm{ppm}$ & 0.00223 & 0.01001 \\
3 & $10 \mathrm{ppm}$ & 0.00226 & 0.01003 \\
4 & $10 \mathrm{ppm}$ & 0.00230 & 0.01001 \\
5 & $10 \mathrm{ppm}$ & 0.00222 & 0.01007 \\
6 & $10 \mathrm{ppm}$ & 0.00224 & 0.01005 \\
& Mean & 0.00225 & 0.01003 \\
& SD & 0.000029 & 0.0000234 \\
& $\% \mathrm{RSD}$ & 1.30 & 0.23 \\
\hline
\end{tabular}

fumarate at $257 \mathrm{~nm}$ and $278 \mathrm{~nm}$ for first derivative spectroscopy are shown in Figures 5, 6, 7, and 8, respectively.

4.3. Accuracy. Recovery studies were performed by standard addition method at three levels, that is, $80 \%, 100 \%$, and $120 \%$. Known amounts of pure salbutamol sulfate and ketotifen fumarate were added to preanalyzed sample of marketed formulation, and they were subjected to analysis by the proposed method. The recovery was verified by estimation of drug in triplicate preparations at each specified concentration level and calculated \%RSD. The mean recoveries were $98.82 \%-$ $101.19 \%$ and $98.34 \%-100.81 \%$ salbutamol sulfate and ketotifen fumarate, respectively. The low value of standard deviation indicates that the proposed method is accurate. Results of recovery studies are shown in Table 1.

\subsection{Precision}

4.4.1. Repeatability. The precision of the instrument was checked by repeated scanning and measurement of the absorbance of solutions $(n=6)$ of salbutamol sulfate $(10 \mu \mathrm{g} /$ $\mathrm{mL})$ and ketotifen fumarate $(10 \mu \mathrm{g} / \mathrm{mL})$ without changing the parameters of the proposed method. The $\%$ RSD values for salbutamol sulfate and ketotifen fumarate were found to be $1.30 \%$ and $0.23 \%$, respectively, at $257 \mathrm{~nm}$ and $278 \mathrm{~nm}$ (Table 2). Low relative standard deviation $(<1)$ indicates that the proposed method is repeatable. 
TABLE 3: Intraday and interday precision data of salbutamol sulfate and ketotifen fumarate for proposed method.

\begin{tabular}{|c|c|c|c|c|c|}
\hline \multirow{2}{*}{ Sr. no. } & \multirow{2}{*}{ Concentration $(\mu \mathrm{g} / \mathrm{mL})$} & \multicolumn{2}{|c|}{ Salbutamol sulfate } & \multicolumn{2}{|c|}{ Ketotifen fumarate } \\
\hline & & Absorbance & $\%$ RSD & Absorbance & $\%$ RSD \\
\hline \multicolumn{6}{|c|}{ Intraday } \\
\hline 1 & 10 & 0.00227 & 0.91 & 0.01004 & 0.15 \\
\hline 2 & 20 & 0.00443 & 0.93 & 0.02063 & 0.12 \\
\hline 3 & 30 & 0.00672 & 0.37 & 0.03128 & 0.05 \\
\hline \multicolumn{6}{|c|}{ Interday } \\
\hline 1 & 10 & 0.00230 & 1.02 & 0.01010 & 0.20 \\
\hline 2 & 20 & 0.00445 & 0.88 & 0.02059 & 0.34 \\
\hline 3 & 30 & 0.00670 & 0.43 & 0.03130 & 0.17 \\
\hline
\end{tabular}

TABLE 4: Regression analysis data and summary of validation parameters for proposed methods.

\begin{tabular}{lcc}
\hline Parameters & \multicolumn{2}{c}{ First derivative method } \\
& $\begin{array}{c}\text { Salbutamol } \\
\text { sulfate }\end{array}$ & $\begin{array}{c}\text { Ketotifen } \\
\text { fumarate }\end{array}$ \\
\hline Wavelength & $257 \mathrm{~nm}$ & $278 \mathrm{~nm}$ \\
Linearity range $(\mu \mathrm{g} / \mathrm{mL})$ & $5-45 \mu \mathrm{g} / \mathrm{mL}$ & $5-35 \mu \mathrm{g} / \mathrm{mL}$ \\
Slope $(\mathrm{m})$ & 0.0002 & 0.0011 \\
Intercept $(\mathrm{c})$ & 0.000006 & 0.0004 \\
Correlation coefficient $\left(r^{2}\right)$ & 0.9998 & 0.9998 \\
LOD $(\mu \mathrm{g} / \mathrm{mL})$ & 0.55 & 0.06 \\
LOQ $(\mu \mathrm{g} / \mathrm{mL})$ & 1.66 & 0.18 \\
\%Recovery & $98.82 \%-101.19 \%$ & $98.34 \%-100.81 \%$ \\
& Precision $(\mathrm{RSD}) \%$ & \\
Repeatability $(n=6)$ & 1.30 & 0.23 \\
Interday $(n=3)$ & $0.43-1.02$ & $0.17-0.34$ \\
Intraday $(n=3)$ & $0.37-0.91$ & $0.05-0.15$ \\
\hline
\end{tabular}

4.4.2. Intermediate Precision (Reproducibility). Precision of both methods was determined in terms of intraday and interday variations (\%RSD). Intra-day precision (\%RSD) was assessed by analyzing standard drug solutions within the calibration range, three times on the same day. Inter-day precision (\%RSD) was assessed by analyzing drug solutions within the calibration range on three different days. The intraday and inter-day precisions were determined, and results of which are given in Table 3.

4.5. LOD and LOQ. LOD and LOQ of the drug were calculated as per ich guideline. LOD values for salbutamol sulfate and ketotifen fumarate were found to be $0.55 \mu \mathrm{g} / \mathrm{mL}$ and $0.061 \mu \mathrm{g} / \mathrm{mL}$, and LOQ values for SAL and KTF were found to be $1.66 \mu \mathrm{g} / \mathrm{mL}$ and $0.18 \mu \mathrm{g} / \mathrm{mL}$ (Table 4 ). These data show that the proposed method is sensitive for the determination of salbutamol sulfate and ketotifen fumarate.

4.6. Analysis of Salbutamol Sulfate and Ketotifen Fumarate in Marketed Formulation. Content of salbutamol sulfate and ketotifen fumarate found in the marketed method from the proposed method is shown in Table 5 . The \% purity was $99.75 \%$ for salbutamol sulfate and $101.90 \%$ for ketotifen fumarate.
TABLE 5: Assay result of marketed formulation.

\begin{tabular}{lcc}
\hline Parameters & $\begin{array}{c}\text { Ketotifen } \\
\text { fumarate }\end{array}$ & $\begin{array}{c}\text { Salbutamol } \\
\text { sulfate }\end{array}$ \\
\hline Actual concentration $(\mu \mathrm{g} / \mathrm{mL})$ & 10 & 20 \\
Concentration obtained $(\mu \mathrm{g} / \mathrm{mL})$ & 10.19 & 19.95 \\
\%Purity & 101.90 & 99.75 \\
\%RSD & 1.41 & 0.37 \\
\hline
\end{tabular}

\section{Conclusion}

In this proposed methods, the linearity was observed in the concentration ranges of $5-45 \mu \mathrm{g} / \mathrm{mL}$ and $5-35 \mu \mathrm{g} / \mathrm{mL}$ with coefficients of correlation $r^{2}=0.9998$ and $r^{2}=0.9998$ for salbutamol sulfate and ketotifen fumarate at $257 \mathrm{~nm}$ and $278 \mathrm{~nm}$, respectively. The result of the analysis of combined mixture by the proposed method was found to be highly reproducible and reliable. The additive present in the combined mixture of the assayed samples did not interfere with determination of salbutamol sulfate and ketotifen fumarate. So, the developed first the derivative UV spectroscopy method is simple, precise, accurate, and reproducible and can be used for simultaneous determination of salbutamol sulfate and ketotifen fumarate in pharmaceutical dosage forms. The method was validated as per international conference on harmonization guidelines.

\section{Acknowledgments}

The authors are thankful to East West Pharma, Uttarakhand, India for providing gratis sample of salbutamol sulfate and ketotifen fumarate as well as to the Department of Pharmaceutical Sciences, Sardar Patel University, Vallabh Vidhyanagar, Gujarat, India, for providing facilities to complete this work successfully.

\section{References}

[1] Indian Pharmacopoeia 2010, vol. 3, Ministry of Health \& Family Welfare, Pharmacopoeia Commission, Ghaziabad, India, 6th edition.

[2] British Pharmacopeia 2010, vol. 3, British Pharmacopoeia Commission Office, London, UK. 
[3] E. A. Martis and D. M. Gangrade, "Reverse phase isocratic hplc method for simultaneous estimation of salbutamol sulphate and beclomethasone dipropionate in rotacaps formulation dosage forms," International Journal of Pharmacy and Pharmaceutical Sciences, vol. 3, pp. 64-67, 2011.

[4] S. Muralidharan and J. Kumar, "High performance liquid chromatographic method development and its validation for salbutamolBritish Journal of Pharmaceutical Research," vol. 2, pp. 228-237, 2012.

[5] G. Murtaza, M. Ahmad, M. A. Madni, and M. W. Asghar, "A new reverse phase hplc method with fluorescent detection for the determination of salbutamol sulfate in human plasma," Bulletin of the Chemical Society of Ethiopia, vol. 23, pp. 1-8, 2009.

[6] A. Manasa, A. U. Mohammed, S. Krantisudha, and I. Sudheerbabu, "Spectrophotometric determination of salbutamol in bulk form and in various dosage forms," The Experiment, vol. 7, pp. 445-449, 2013.

[7] A. K. Mishra, M. Kumar, A. Mishra, A. Verma, and P. Chattopadhyay, "Validated UV spectroscopic method for estimation of Salbutamol from tablet formulations," Archives of Applied Science Research, vol. 2, pp. 207-211, 2010.

[8] P. A. Patel, M. N. Dole, P. S. Shedpure, and S. D. Sawant, "Spectrophotometric simultaneous estimation of salbutamol and Ambroxol in bulk and formulation," Asian Journal of Pharmaceutical and Clinical Research, vol. 4, no. 3, pp. 42-45, 2011.

[9] http://www.rxlist.com/zaditor-drug.htm, 2013.

[10] S. Muralidharan, L. B. Han, J. L. Yew Ming, S. Kartigayam, and S. A. Dhanaraj, "Simple and accurate estimation of ketotifen fumarate by RP-HPLC," International Journal of Pharmaceutical, Chemical and Biological Sciences, vol. 2, pp. 392-396, 2012.

[11] M. H. Semreen, "Optimization and validation of HPLC method for the analysis of ketotifen fumarate in a pharmaceutical formulation," Bulletin of Pharmaceutical Sciences, vol. 28, pp. 291-296, 2005.

[12] S. Muralidharan, L. B. Han, J. L. Yew Ming, S. J. Awang, and S. A. Dhanaraj, "Development of a spectrophotometry method for the estimation of ketotifen fumarate in bulk and the pharmaceutical tablet dosage form," Der Pharmacia Lettre, vol. 4, pp. 1339-1343, 2012.

[13] I. Singhvi and D. Sachdeva, "Spectrophotometric estimation of ketotifen fumarate from tablet formulations," Indian Journal of Pharmaceutical Sciences, vol. 71, no. 1, pp. 66-68, 2009.

[14] "ICH Tripartite Guideline, Q2R1, Validation of Analytical Procedure: Text and Methodology," 2005.

[15] "ICH, Q2B, Validation of Analytical Procedures, Text and Methodology," Geneva, Switzerland, 1996. 

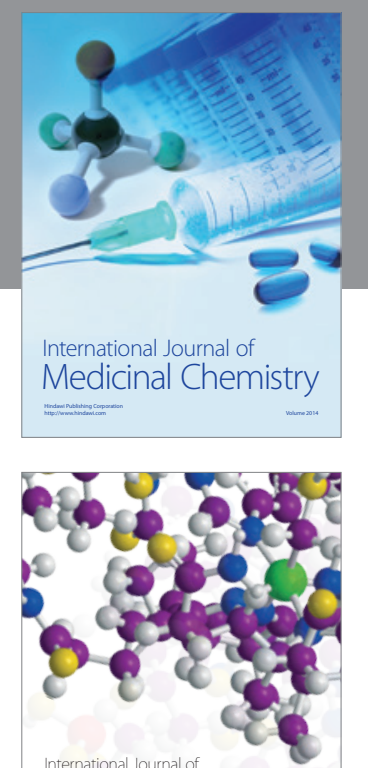

\section{Carbohydrate} Chemistry

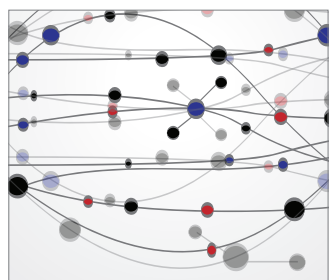

The Scientific World Journal
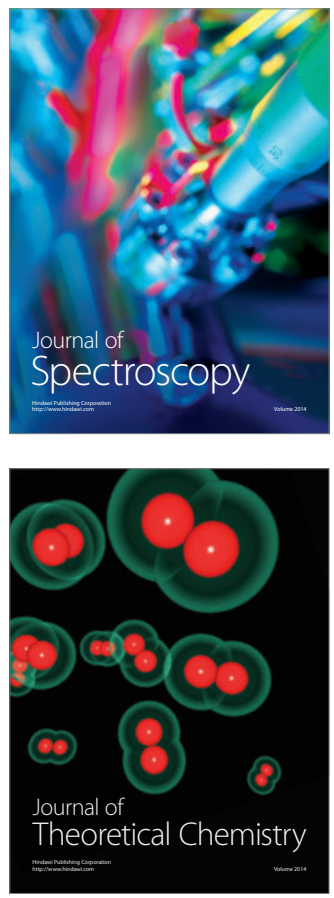
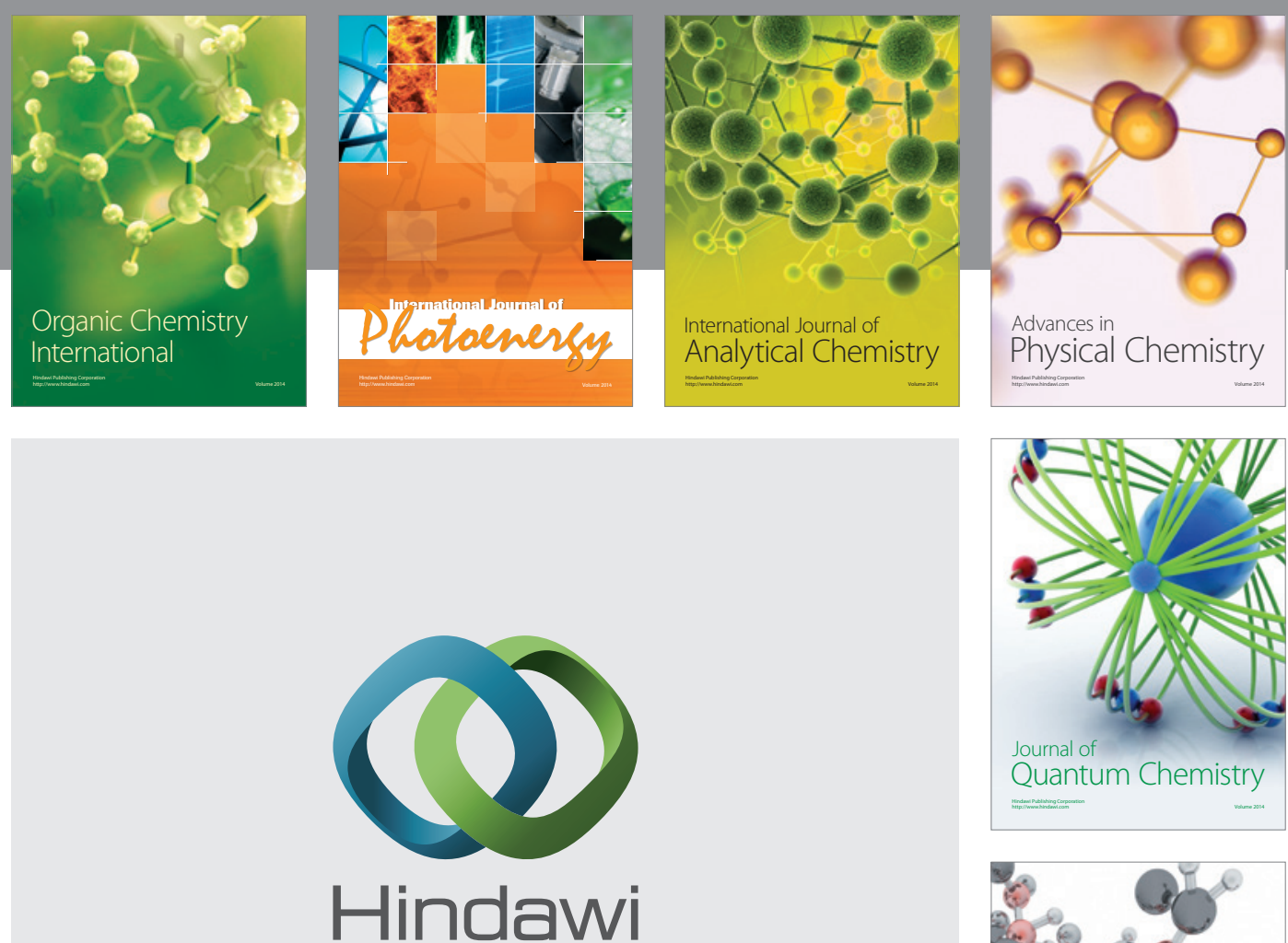

Submit your manuscripts at

http://www.hindawi.com

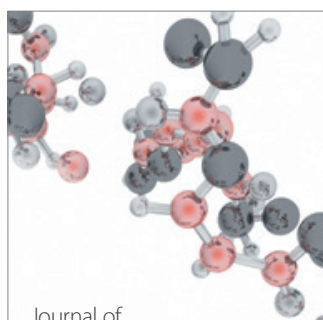

Analytical Methods

in Chemistry

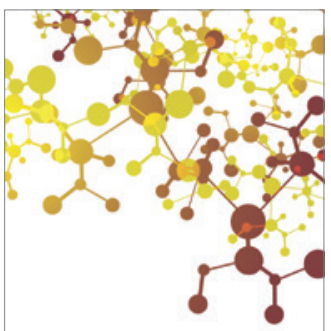

Journal of

Applied Chemistry

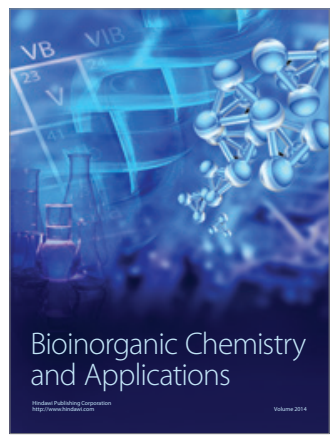

Inorganic Chemistry
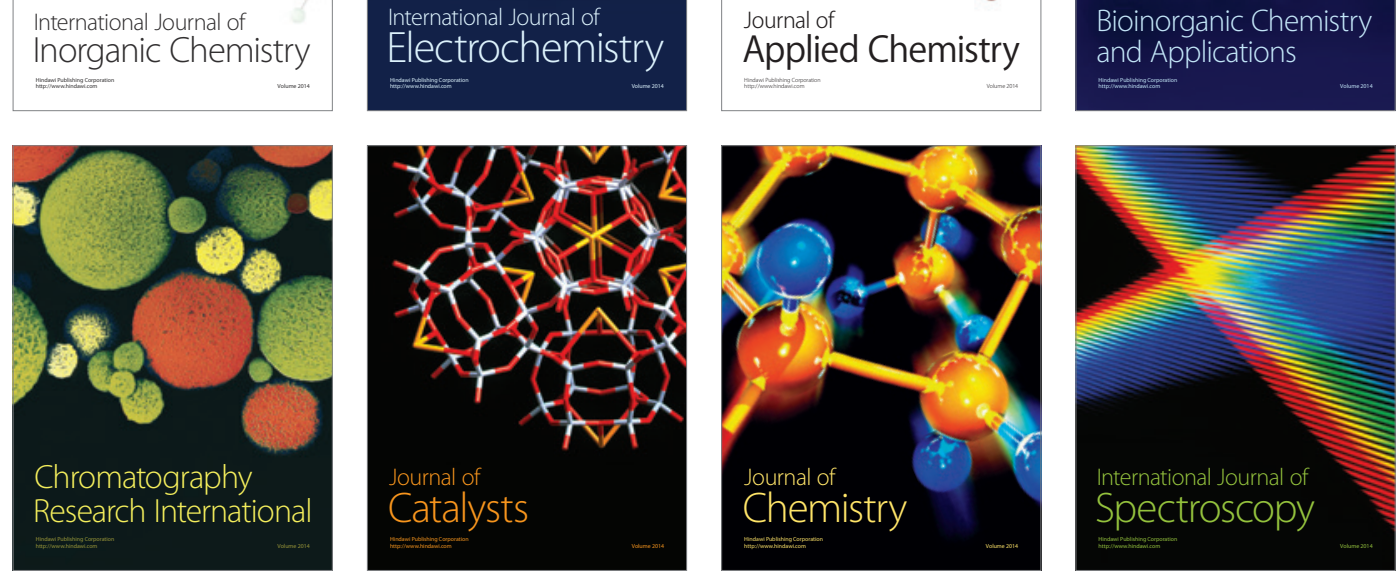